\title{
Impact of CSR Perception on Brand Image, Brand Attitude and Buying Willingness: A Study of a Global Café
}

\author{
Shwu-Ing $\mathrm{Wu}^{1} \&$ Wen-Hsuan Wang ${ }^{1}$ \\ ${ }^{1}$ Department of Business Administration, National Chin-Yi University of Technology, Taiwan, R.O.C. \\ Correspondence: Shwu-Ing Wu, Professor of Department of Business Administration, National Chin-Yi \\ University of Technology, No.57, Section 2, Chungshan Road, Taiping, Taichung, Taiwan 411, R.O.C. Tel: \\ 886-4-2392-4505. E-mail: wusi@ncut.edu.tw
}

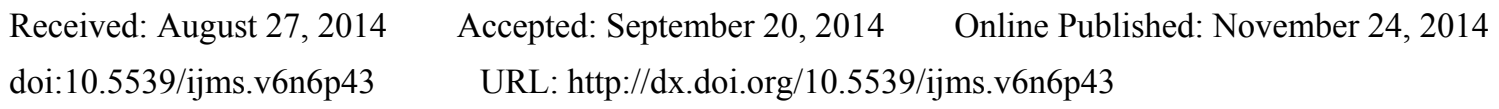

\begin{abstract}
In recent years, corporate social responsibility (CSR) has been the subject of increasing public scrutiny, and consumers have become more concerned about whether enterprises are contributing to the betterment of society. This research takes Starbucks as an example in the exploration of the impact of different generations' perceptions of CSR on future buying willingness.

The research survey collected 624 validated questionnaires. The results show that different generations have significantly different attitudes in two influential ways: (1) in the X-generation, the influence of environmental CSR on experiential brand image, and the influence of brand attitude on future buying willingness, are more significant than with the Y-generation; (2) in the Y-generation, the impact of community CSR on experiential brand image, and the impact of symbolic brand awareness on brand attitude are more significant than with the $\mathrm{X}$-generation. The research found that a business undertaking a successful policy of CSR could lead consumers to purchase its products. Ultimately the business will have an opportunity to fulfill its goal of sustainability.
\end{abstract}

Keywords: corporate social responsibility, brand image, brand attitude

\section{Introduction}

In recent years, with industrial development and social progress, issues of corporate social responsibility (CSR) have been receiving increased public attention. By way of contributing to the well-being of society, enterprises have striven to present good business images, and consumers no longer tend to seriously examine corporate feedback to society (Esrock \& Leichty, 1998; Goi \& Yong, 2009; Alsmadi \& Alnawas, 2012).

There are two reasons why CSR is getting more attention: firstly, enterprises are getting to understand that CSR is a key to business success, and secondly, nonprofit organizations need support, and this encourages enterprises to participate (Lichtenstein, Drumwright, \& Braig, 2004). Furthermore, most enterprises believe that carrying out CSR can make themselves recognizable to the public (Kotler \& Lee, 2005), because undertaking social responsibilities allows a company to build good images and a good reputation (Fombrun \& Shanley, 1990; Giannarakis \& Theotokas, 2011). Therefore, a company carrying out its policy of social responsibility can enhance its good image and create a competitive edge (Porter \& Kramer, 2006; Boonpattarakan, 2012).

On the other hand, a company can also use its distinctive brand images to promote its competitiveness; that is, endowing unique characteristics and images to its brand name and passing its message to consumers, so that their distinct feelings about the brand are positively affected. As a result, brand image management is a key point in marketing strategy. Using a crystal clear brand image for communication can drive customers to identify needed products based on the brand name (Park, Jaworski, \& Maclnnis, 1986), and differentiate the branded products from those of other competitors (Reynolds \& Gutman, 1984). However, CSR is a key element in the promotion of brand images ( $\mathrm{He} \& \mathrm{Li}, 2011)$. In fact, CSR and corporate brand images are actually inextricably bound, but there are very few studies on the related topics. This is one of the motives for this research.

Fournier (1998) suggested that if the functionality provided by a brand met consumers' needs, then consumers would be psychologically linked to the brand, and irreplaceably bound with it. Brandt (1998) pointed out that an enterprise could combine its products' functional and non-functional images and features to drive the motivations of customers and brand bonding; that is, if the branded products are satisfactory, consumers will be impressed 
and develop positive brand attitudes toward the products, and ultimately build persistent loyalty toward the brand. Therefore, the relationship between business brand image and consumers' brand attitudes and loyalty deserves an in-depth discussion. This is the second motive of this research.

Based on the above, this research aims to explore the impact of consumers' perception of CSR on brand image recognition, brand attitude, satisfaction, loyalty, and buying willingness. Moreover, it compares the differences of different generations. Starbucks was selected as the target of this study because the company has initiated its brand commitment with the "Starbucks Love ProjectTM". In this, the company has attached great importance to the issues of pollution reduction, starting from the very source where the coffee beans are harvested. Meanwhile, the company is also participating in local community construction and in community services, in an effort to spread out good things to the world.

\section{Literature Reviews}

\subsection{Consumers' Perception of CSR}

CSR refer to the activities conducted by enterprises to pursue social values and satisfy social needs (Lichtenstein et al., 2004). Consumers' recognition of enterprises became more rigorous as they were made more aware of CSR, and their attitudes would ultimately affect their willingness to buy (Mejri \& De Wolf, 2012).

Enterprises have also begun looking to their CSR for all stakeholders, and adjusted their corresponding policy. CSR includes many aspects, and research must investigate such aspects as follows (Clarkson, 1995; Freeman, 1984; Waddock et al., 2002; Brunk, 2010):

(1). Customer oriented CSR: Providing customers high quality products and services to fulfill customer needs.

(2). Employee oriented CSR: Providing fair evaluation, promotion and compensation for employees.

(3). Environment oriented CSR: Supporting environmental activities, and incorporating environmental sustainability into business operations.

(4). Economic oriented CSR: Offering products and services with reasonable pricing to meet social needs, and the sharing of profits with investors.

(5). Community oriented CSR: Supporting charity institutions and sponsoring cultural, sporting and educational activities, to fulfill the commitment of improving communities.

This research measures consumers' perception of CSR using the above 5 aspects.

\subsection{Brand Image}

A good brand can confirm a consumer's favorable impression, and enhance his/her recognition of the products (Grewal \& Krishnan, 1998). When a brand image is strong in a consumer's mind, the products can easily obtain greater attraction, thus a consumer buying spree could be triggered (Shamma \& Hassan, 2011). Park, Jaworski and Maclnnis (1986) argued that brand image is a perceptual phenomenon affected by corporate communication activities, by means of which consumers can be led to freely associate their minds to the branded products. The brand image, however, can be further divided into three constructs, which are functional, symbolic and experiential, and are detailed as follows:

(1). Functional image: The product function can help consumers solve their consumer issues and prevent potential problems.

(2). Symbolic image: The brand can satisfy consumers' inner desires such as enhancing self-value, social status, self-recognition, etc.

(3). Experiential image: The brand can satisfy consumers' pursuance of diversity and stimulation so as to provide them experiential pleasures.

\subsection{Brand Attitude}

Brand attitude is the preference for a specific brand after a buyer has evaluated the features of all relevant products of different brands (Howard, 1994). Brand attitude takes a pivotal position because it could be used to predict consumers' buying willingness and related behaviors (Arjun, 1999). Enterprises must understand what consumers think of the brand, and further explore their attitudes toward the brand. Therefore, brand attitude should be an indication of consumers' likes or dislikes which could be used to predict consumers' buying willingness and brand loyalty (Burton \& Garretson, 1998).

\subsection{Satisfaction}

Satisfaction is a judgment of pleasures from the product itself or from its attributes (Oliver, 1980). Satisfaction 
also is the highs and lows of pleasures experienced by customers, which originates from a comparison of customers' cognition of the product performance against customers' anticipation toward the product (Kotler, 1999). Increasing customer satisfaction could help businesses save costs, create profits and establish reputations (Reichheld, 1996).

\subsection{Brand Loyalty}

Brand loyalty can be divided into behavioral loyalty and attitudinal loyalty (Farr \& Hollis, 1997). It contains three elements: consumers' buying behavior, emotional attachment to the brand product and the influence of social norms (Gounaris \& Stanthakopoulos, 2004). Brand loyalty can be measured by four elements: (1) repetitive buying; (2) expedited buying; (3) buying various products of the same brand; (4) limited changing to other brands (Blatterg \& Neslin, 1990).

\subsection{Future Buying Willingness}

Buying willingness comes from consumers' appraisals and brand attitude toward the products, coupled with external stimulating factors such as advertising messages to create a buying willingness. Buying willingness means the probability of consumers' willingness to buy the products (Dodds, Monron, \& Grewal, 1991). Higher buying willingness means a higher probability of actual buying (Schiffman \& Kanuk, 2000). Buying willingness is a significant and influential factor of buying behavior, which results from consumers' beliefs in the products or brands, as well as their brand attitude, quality appraisal and value cognition. Consumers' cognitive values can used to measure buying willingness, which includes the probability of buying, wanting to buy, and seriously considering to buy (Zeithaml, 1988).

\section{Research Hypotheses}

\subsection{The Impact of Consumer Perception of CSR on Brand Image}

Enterprises carrying out CSR provide a foundation for consumer evaluation (Maignan \& Ferrell, 2001; Boonpattarakan, 2012). Customer oriented CSR can fulfill customers' needs (Clarkson, 1995; Brunk, 2010). Therefore, initiating a CSR approach for customers could encourage consumers to actively connect with the brand (Pivato et al., 2008; He \& Li, 2011), and create a positive brand image in the consumers' minds (Becker-Olsen et al., 2006; Alexander, Francis, Kyire, \& Mohammed, 2014).

Because brand image can be divided into three dimensions: functional image, symbolic image, and experiential image, this research, therefore, proposes the following hypotheses:

H1a: An enterprise undertaking its social responsibility for customers will have a positive impact on its functional brand image.

H1b: An enterprise undertaking its social responsibility for customers will have a positive impact on its symbolic brand image.

H1c: An enterprise undertaking its social responsibility for customers will have a positive impact on its experiential brand image.

Enterprises carrying out employee oriented CSR, such as in providing fair evaluation, promotion and compensation can enhance brand image (Waddock et al., 2002). Furthermore, enterprises carrying out CSR for employees can produce internal effects to positively strengthen the corporate brand image (Fombrun \& Shanely, 1990). Therefore, this research proposes the following hypotheses:

H2a: An enterprise undertaking its social responsibility for employees will have a positive impact on its functional brand image.

$\mathrm{H} 2 \mathrm{~b}$ : An enterprise undertaking its social responsibility for employees will have a positive impact on its symbolic brand image.

H2c: An enterprise undertaking its social responsibility for employees will have a positive impact on its experiential brand image.

Environmentally oriented CSR, such as the support of environmental activities and the incorporation of environmental sustainability into the business operations will strengthen brand image in consumers' minds (Clarkson, 1995). Brown and Dacin (1997) stated that environmental CSR actions could enhance organizational performance and improve a corporate brand image. A company that cares about environmental protection and seeks to maintain the natural environment thus has its brand image enhanced (Sen et al., 2006). Therefore, this research proposes the following hypotheses:

H3a: An enterprise undertaking its social responsibility for the environment will have a positive impact on its 
functional brand image.

H3b: An enterprise undertaking its social responsibility for the environment will have a positive impact on its symbolic brand image.

H3c: An enterprise undertaking its social responsibility for the environment will have a positive impact on its experiential brand image.

Lichtenstein et al. (2004) proposed that if consumers were more aware that enterprises were carrying out economically oriented CSR such as reasonable pricing, sharing profits with investors, it would enhance the enterprise's brand image. Economically oriented CSR may influence consumers' appraisals and create for the consumers a good perception of enterprise brand image (Sen et al., 2006). Therefore, this research proposes the following hypotheses:

H4a: An enterprise undertaking its social responsibility towards its country's economy will have a positive impact on its functional brand image.

H4b: An enterprise undertaking its social responsibility towards its country's economy will have a positive impact on its symbolic brand image.

H4c: An enterprise undertaking its social responsibility towards its country's economy will have a positive impact on its experiential brand image.

If an enterprise carries out community oriented CSR such as supporting charitable institutions and sponsoring charitable activities, it will enhance its brand image (Waddock et al., 2002; Brunk, 2010). If an enterprise carries out CSR towards its community, it will effectively promote its brand image including functional image, symbolic image and experiential image (Park, Jaworski, \& Maclnnis, 1986). Therefore, this research proposes the following hypotheses:

H5a: An enterprise undertaking its social responsibility towards its community will have a positive impact on its functional brand image.

H5b: An enterprise undertaking its social responsibility towards its community will have a positive impact on its symbolic brand image.

H5c: An enterprise undertaking its social responsibility towards its community will have a positive impact on its experiential brand image.

\subsection{The impact of Brand Image on Brand Attitude}

Consumers tend to have more favorable brand attitudes and buying willingness for familiar products with good brand images (Kamins \& Marks, 1991). Laroche et al. (1996) evidenced that the more that consumers were familiar with a product, and the greater their confidence in a product, the more favorable was their attitude to that product. Since brand image can be divided into functional image, symbolic image and experiential image, such images directly affect consumers' brand attitudes (Park et al., 1986). Therefore, this research proposes the following hypotheses:

H6: The functional brand image has a positive impact on consumers' brand attitudes.

H7: The symbolic brand image has a positive impact on consumers' brand attitudes.

H8: The experiential brand image has a positive impact on consumers' brand attitudes.

\subsection{The Impact of Consumers' Brand Attitudes on Satisfaction}

Arjun (1999) pointed out that to completely grasp consumers' decision-making and behaviors, it is necessary to understand consumers' varied thinking and their appraisals of the brand. A good brand may increase consumer satisfaction and encourage them to recommend the brand products to others (Aaker, 1991). Jamal and Goode (2001) evidenced that consumers who had positive attitudes toward a brand would have strong preferences for the brand products, thus gaining a lot of satisfaction from those products.

Brand image is significantly correlated with consumer appraisals and corporate reputation; the better the brand image, the higher the consumer appraisal (Cretu \& Brodie, 2007). When brand attributes are associated with positive images, customers tend to have more favorable brand attitudes, thus feeling greater satisfaction with the brand (Romaniuk \& Sharp, 2003). Therefore, this research proposes the following hypothesis:

H9: Favorable consumers' brand attitudes have a positive impact on satisfaction. 


\subsection{The Impact of Consumers' Brand Attitudes on Loyalty}

Brand attitudes can directly affect the brand loyalty of the buyer, and indirectly affect the brand assets (Arjun, 1999). This statement shows that brand attitudes can directly affect buying willingness and future acts of brand loyalty.

When consumers have a tendency toward a specific brand attitude, this attitude may be regarded as the indication of a tendency toward future loyalty (Bennett \& Rundle-Thiele, 2002). Therefore, loyalty is basically affected by consumers' brand attitudes (Priester et al., 2004). As a result, this research proposes the following hypothesis:

H10: Consumers' brand attitudes have a positive impact on brand loyalty.

\subsection{The Impact of Consumers' Brand Attitudes on Future Buying Willingness}

Branding influences the consumers' recognition of product quality, and the brand attitude formed by this influence will determine the consumers' buying decisions (Dodds et al., 1991; Zeithaml, 1988). When consumers make buying decisions, they refer to their brand preference and, as a result, the consumers' brand attitudes determine their decisions (Neal, 2000). Thus, positive brand attitude will increase future buying willingness (Kotler, 2000). Therefore, this research proposes the following hypothesis:

H11: Consumers' brand attitudes have a positive impact on future buying willingness.

\subsection{The Impact of Consumer Satisfaction on Brand Loyalty}

Customer satisfaction means that the product or service meets the customer's requirements or even exceeds their expectation, so that the customer is encouraged to make repeat purchases (Kotler, 2000). Customer satisfaction affects customer loyalty, since satisfied customers increase their number of purchases (Reichheld \& Sasser, 1990). Thus, customer satisfaction positively affects a customer's purchasing motivation, and so displays customer loyalty (Anderson \& Sullivan, 1993). Therefore, this research proposes the following hypothesis:

H12: Consumer satisfaction has a positive impact on loyalty.

\subsection{The Impact of Consumer Loyalty on Future Buying Willingness}

A loyal consumer is a guarantee of competitiveness (Aaker, 1996). Oliver (1999) believed that loyalty could be described as a consumer's willingness to repurchase. Thus, the greater the consumer brand loyalty, the stronger is the willingness to buy. Reichheld and Sasser (1990) proposed that satisfied consumers have their loyalty to the enterprise strengthened, which indicates a greater probability of their future repetitive repurchasing. Thus, this research proposes the following hypothesis:

H13: Consumer loyalty has a positive impact on future buying willingness.

\subsection{The Perceptions of Different Generations on the Impact of CSR on Consumer Trends}

Consumer decision-making processes could be generation-sensitive; these processes include consumer awareness, brand benefits and brand preference (Moore et al., 2002). Therefore, the generation-sensitive brand preference has received a great deal of attention from scholars, and many researchers have been supportive to the exploration of generation-sensitive consuming behaviors, specially with regards to their influence on choosing brands and products (Moore, Wilkie, \& Lutz, 2002; Cotte \& Wood, 2004; Mandrik, Fern, \& Bao, 2005). Many scholars believe that the generation-sensitive consuming behaviors vary due to age, marital status, parental relationships, and culture (Childers \& Rao, 1992; Heckler et al., 1989; Shah \& Mittal, 1997). Accordingly, different generations have different consumer patterns. Therefore, this research proposes the following hypothesis:

H14: Different generations have significantly different influences on the CSR model.

\section{Research Design}

\subsection{Research Framework}

This research explores the impact of consumers' perceptions of CSR on brand image, brand attitude, satisfaction, loyalty, and buying willingness. The five CSR aspects, customer, employee, environment, economy and community, are taken as independent variables; three brand image aspects, functional image, symbolic image and experiential image are taken as intermediary variables; the dependent variables are satisfaction, loyalty and buying willingness. This four-layer relationship has been built into the framework of this research, as shown in Figure 1. 


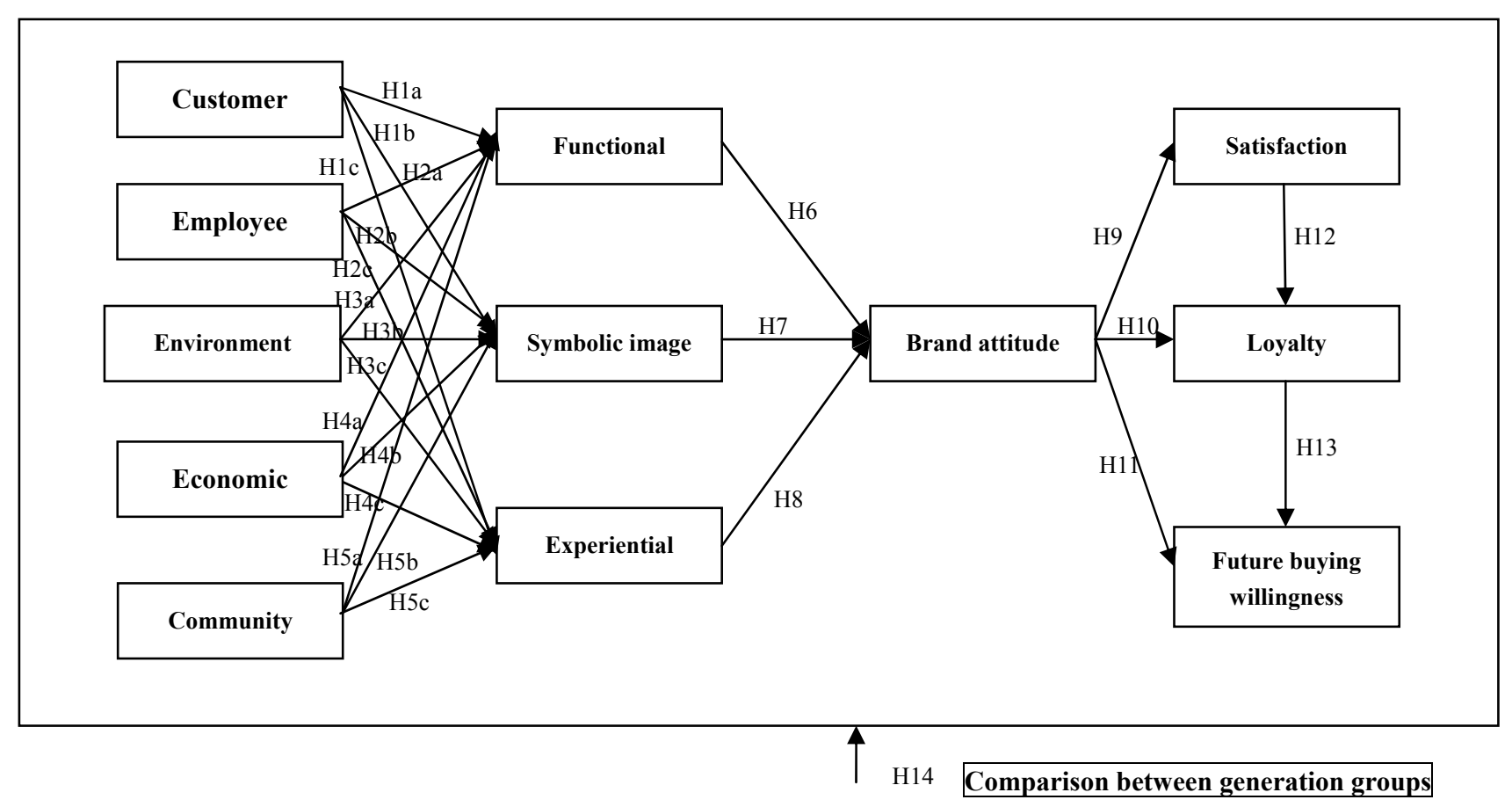

Figure 1. Research framework

\subsection{Research Variables}

This research first undertook the design of a draft questionnaire draft based on the aforementioned theories and literatures. The questionnaire was tested through pre-test and pilot test. Then a normal survey was carried out by interviewing Starbucks customers. The questionnaire has 7 parts: perception of CSR, brand image, brand attitude, satisfaction, loyalty, buying willingness and interviewee's background information. The first 6 parts use Likert 7 point scale ranging from 1 "highly disagree" to 7 "highly agree"; the 7th part, the demographic data is measured by nominal scale. The design process is outlined below.

\subsection{Pretest and Pilot}

To ensure the effectiveness of the questionnaire, it was subjected to a pretest and pilot two-phase modification. For the pretest, a convenient sampling was used to pick 30 consumers for in depth interviews. The pretest results showed that some questions had vague meanings, thus these words and sentences were modified for clearer understanding.

A further convenient sampling was undertaken to pick 100 customers for the pilot study in order to gain data for reliability and validity analysis. The results showed that the Cronbach $\alpha$ value was greater than 0.7 for all the measurement dimensions and the item-to-total correlation coefficients were all greater than 0.5 , indicating that all the measurement dimensions had very good reliability (Nunnally, 1978; Kerlinger, 1978). The factor analysis showed that all the measurement aspects' eigenvalues were greater than 1 , and the accumulative explained variations were greater than 0.5 , while all the variables' factor loadings were greater than 0.6 , indicating that all the measurement dimensions had convergent validity (Kerlinger, 1978; Kaiser, 1958). Therefore, this questionnaire was used for formal interview and survey.

\section{Research Results}

\subsection{Reliability and Validity Analysis}

The study interviewed Starbucks consumers who were more than 18 years of age. There were 700 questionnaires sent out based on the convenient sampling: 76 invalid copies were discounted, leaving 624 valid copies collected with an effective recovery rate of $89.14 \%$.

This research used the Cronbach $\alpha$ and correlation coefficients to test the reliability. If the Cronbach $\alpha$ value was greater than 0.7 (Nunnally, 1978), and the item-to-total correlation coefficient was greater than 0.5 (Kerlinger, 
1978) that was taken to mean that the questionnaire had high reliability. The results show that all the Cranach $\alpha$ value and correlation coefficients were acceptable within the standard. As a result, the overall reliability of this research questionnaire proved to be good, as shown in Table 1.

A factor analysis was conducted to verify its convergent validity. According to Kaiser (1958), to satisfy the criteria, the extracted factor eigenvalue had to be greater than 1 , the factor loadings all greater than 0.5 , and the cumulative explained variations greater than 0.5 . The results show that all the indexes of this research were greater than or close to the standard, so the convergent validity of the questionnaire proved to be excellent.

Table 1. Analysis of the reliability and validity of the formal questionnaire

\begin{tabular}{|c|c|c|c|c|c|}
\hline Measuring indicator & $\begin{array}{l}\text { Item-to-total } \\
\text { relational } \\
\text { coefficient }\end{array}$ & $\begin{array}{l}\text { Factor } \\
\text { loading }\end{array}$ & Eigenvalue & $\begin{array}{l}\text { Accumulative } \\
\text { explained } \\
\text { variation (\%) }\end{array}$ & $\begin{array}{l}\text { Cronbach's } \\
\text { a value }\end{array}$ \\
\hline \multicolumn{6}{|l|}{ Customer oriented CSR (customer aspect) } \\
\hline $\begin{array}{l}\text { 1.Starbucks provides products and services that meet consumers' } \\
\text { needs. }\end{array}$ & 0.717 & 0.846 & 2.863 & 71.571 & 0.866 \\
\hline 2.Starbucks treats customers with ethical and honest attitude. & 0.753 & 0.870 & & & \\
\hline 3.Starbucks thinks from consumer's point of view. & 0.707 & 0.838 & & & \\
\hline 4.Starbucks can undertake the product liability. & 0.694 & 0.830 & & & \\
\hline \multicolumn{6}{|l|}{ Employees oriented CSR (employee aspect) } \\
\hline 1.Starbucks employees work highly efficiently. & 0.763 & 0.856 & 3.550 & 71.010 & 0.897 \\
\hline 2.Starbucks employees have very good service attitude. & 0.800 & 0.881 & & & \\
\hline 3.I feel the Starbucks employees love their company. & 0.738 & 0.837 & & & \\
\hline 4.I feel the Starbucks employees are full of energy and passion. & 0.797 & 0.879 & & & \\
\hline 5.I feel Starbucks provides a good work environment. & 0.635 & 0.753 & & & \\
\hline \multicolumn{6}{|l|}{ Environment oriented CSR (environment aspect) } \\
\hline 1.Starbucks has reduced sales of over-packed products. & 0.617 & 0.772 & 2.859 & 71.487 & 0.866 \\
\hline 2.Starbucks looks to eco-friendly production procedure. & 0.788 & 0.891 & & & \\
\hline $\begin{array}{l}\text { 3.Starbucks undertakes the responsibility for environmental } \\
\text { protection. }\end{array}$ & 0.749 & 0.869 & & & \\
\hline 4.Starbucks has been doing recycling for environmental protection. & 0.713 & 0.845 & & & \\
\hline \multicolumn{6}{|l|}{ Economic oriented CSR (economic aspect) } \\
\hline 1.Starbucks can help promote industrial development. & 0.708 & 0.839 & 2.830 & 70.743 & 0.861 \\
\hline 2.Starbucks' marketing approach is very attractive. & 0.687 & 0.827 & & & \\
\hline 3.Starbucks is always innovative in new product development. & 0.717 & 0.846 & & & \\
\hline 4.Starbucks can help our country's economic development. & 0.724 & 0.852 & & & \\
\hline \multicolumn{6}{|l|}{ Community oriented CSR (community aspect) } \\
\hline 1.Starbucks is active in public welfare activities. & 0.826 & 0.904 & 3.306 & 82.656 & 0.930 \\
\hline $\begin{array}{l}2 \text {.Starbucks has long been making donations to poverty-stricken } \\
\text { areas. }\end{array}$ & 0.881 & 0.937 & & & \\
\hline $\begin{array}{l}\text { 3.Starbucks has been holding regular social events to promote } \\
\text { healthy diet concepts. }\end{array}$ & 0.867 & 0.928 & & & \\
\hline 4.Starbucks has been sponsoring art and cultural activities & 0.771 & 0.866 & & & \\
\hline \multicolumn{6}{|l|}{ Brand image (functional image) } \\
\hline $\begin{array}{l}\text { 1.Starbucks provides product appearance and packaging that meet } \\
\text { consumers' needs. }\end{array}$ & 0.608 & 0.781 & 2.672 & 66.792 & 0.828 \\
\hline 2.Choosing Starbucks is wise. & 0.580 & 0.752 & & & \\
\hline 3.Starbucks provides excellent services. & 0.727 & 0.867 & & & \\
\hline 4.Starbucks product quality is satisfactory. & 0.725 & 0.864 & & & \\
\hline \multicolumn{6}{|l|}{ Brand image (symbolic image) } \\
\hline 1.Enjoying Starbucks products is trendy. & 0.784 & 0.884 & 3.061 & 76.513 & 0.897 \\
\hline 2.Enjoying Starbucks products is a symbol of social status. & 0.814 & 0.904 & & & \\
\hline 3.Starbucks is a leading brand. & 0.807 & 0.898 & & & \\
\hline 4. Starbucks products and brand match my individual image. & 0.682 & 0.810 & & & \\
\hline \multicolumn{6}{|l|}{ Brand image (experiential image) } \\
\hline 1.Starbucks products interest me. & 0.739 & 0.854 & 3.018 & 75.457 & 0.891 \\
\hline 2.Starbucks services make me feel warm and comfortable. & 0.797 & 0.893 & & & \\
\hline 3.Starbucks shop environment offers me enjoyment. & 0.800 & 0.894 & & & \\
\hline $\begin{array}{l}\text { 4.Starbucks products pursue diversified consumer needs in daily } \\
\text { life. }\end{array}$ & 0.706 & 0.831 & & & \\
\hline
\end{tabular}




\begin{tabular}{|c|c|c|c|c|c|}
\hline \multicolumn{6}{|l|}{ Brand attitude } \\
\hline 1.I like Starbucks products. & 0.817 & 0.889 & 3.788 & 75.764 & 0.918 \\
\hline 2.I have a good impression on Starbucks products as a whole. & 0.803 & 0.882 & & & \\
\hline 3.Starbucks products can provide me the feeling of enjoyment. & 0.849 & 0.910 & & & \\
\hline 4.I trust Starbucks products. & 0.776 & 0.859 & & & \\
\hline 5.I believe the Starbucks product style is very suitable to mine. & 0.711 & 0.808 & & & \\
\hline \multicolumn{6}{|l|}{ Satisfaction } \\
\hline 1.Starbucks products or services meet my expectation. & 0.839 & 0.912 & 3.295 & 82.366 & 0.927 \\
\hline 2.I'm satisfied with the Starbucks products or services. & 0.848 & 0.919 & & & \\
\hline 3.The experience of taking Starbucks products or services is joyful. & 0.839 & 0.912 & & & \\
\hline 4.I'm happy that I've bought Starbucks products. & 0.802 & 0.887 & & & \\
\hline \multicolumn{6}{|l|}{ Loyalty } \\
\hline 1.Starbucks is my top choice. & 0.829 & 0.912 & 3.078 & 76.962 & 0.900 \\
\hline 2.I'd love to try Starbucks new products. & 0.634 & 0.772 & & & \\
\hline 3.I'm loyal to Starbucks brand. & 0.856 & 0.927 & & & \\
\hline $\begin{array}{l}\text { 4.I'd be happy to spend time in search for Starbucks product } \\
\text { information. }\end{array}$ & 0.793 & 0.889 & & & \\
\hline \multicolumn{6}{|l|}{ Future buying willingness } \\
\hline 1.I'll continue buying Starbucks products. & 0.804 & 0.906 & 2.876 & 71.896 & 0.864 \\
\hline 2.I'll recommend Starbucks products to others. & 0.816 & 0.912 & & & \\
\hline $\begin{array}{l}\text { 3. Whenever Starbucks has promotional sales, I increase my } \\
\text { purchase volume. }\end{array}$ & 0.598 & 0.760 & & & \\
\hline 4.I'll be happy to pay more for Starbucks products. & 0.655 & 0.804 & & & \\
\hline
\end{tabular}

\subsection{Analysis of the Full Model}

This research used the AMOS software to perform the linear structural relation model analysis, for a better understanding of the causality and correlation among the variables. An excellent model was established in accordance with the following parameters: the indicators of GFI, NFI, RFI and CFI were all greater than 0.9 (Joreskog \& Sorbom, 1989); AGFI greater than 0.8 (Segars \& Grover, 1993); RMESA less than 0.08 (Brown and Cudek, 1993); and the ratio ( $\chi 2 / \mathrm{df})$ was not greater than 3 (Camines \& MacIver, 1981). The analysis results showed that the values of GFI, AGFI, NFI, RFI and CFI were 0.892, 0.867, 0.937, 0.926 and 0.972, respectively, while RMESA and $\chi^{2} / \mathrm{df}$ were, respectively, 0.035 and 1.746 . Therefore, the full model of this research proved to be excellent and acceptable.

The path analysis showed that only three hypotheses were false: the customer aspect of CSR to experiential brand image ( $\mathrm{H} 1 \mathrm{c})$, the environment aspect of CSR to functional brand image (H3a), and the environment aspect of CSR to experiential brand image $(\mathrm{H} 3 \mathrm{c})$; all the rest of the hypotheses were confirmed to be true. The results are shown in Table 2.

Table 2. Full model and competing model analysis

\begin{tabular}{|c|c|c|c|c|c|}
\hline \multirow[t]{2}{*}{ Path } & & \multicolumn{3}{|c|}{ Standardized parameter estimate } & \multirow{2}{*}{$\begin{array}{l}\text { Generation X vs. } \\
\text { Generation Y } \\
\text { t-test(H14) }\end{array}$} \\
\hline & & Full & Generation X & Generation Y & \\
\hline \multirow{15}{*}{ CSR } & customer aspect $\rightarrow$ functional image(H1a) & $0.199 * *$ & $0.361^{*}$ & $0.192 *$ & 1.195 \\
\hline & customer aspect $\rightarrow$ symbolic image $(\mathrm{H} 1 \mathrm{~b})$ & $0.175^{*}$ & 0.237 & 0.170 & 0.322 \\
\hline & customer aspect $\rightarrow$ experiential image $(\mathrm{H} 1 \mathrm{c})$ & 0.031 & -0.083 & 0.114 & -1.413 \\
\hline & employee aspect $\rightarrow$ functional image(H2a) & $0.445^{* * *}$ & $0.374 * * *$ & $0.453 * * *$ & -0.761 \\
\hline & employee aspect $\rightarrow$ symbolic image $(\mathrm{H} 2 b)$ & $0.307 * * *$ & 0.204 & $0.319 * *$ & -1.019 \\
\hline & employee aspect $\rightarrow$ experiential image $(\mathrm{H} 2 \mathrm{c})$ & $0.376^{* * *}$ & $0.425 * * *$ & $0.311 * * *$ & 0.462 \\
\hline & environment aspect $\rightarrow$ functional image $(\mathrm{H3}$ a) & -0.004 & 0.026 & -0.075 & 1.060 \\
\hline & environment aspect $\rightarrow$ symbolic image $(\mathrm{H} 3 b)$ & $-0.237 * * *$ & $-0.247 * *$ & $-0.290 * * *$ & 0.601 \\
\hline & environment aspect $\rightarrow$ experiential image $(\mathrm{H3c})$ & -0.013 & 0.119 & $-0.147 *$ & $2.671 * *$ \\
\hline & economic aspect $\rightarrow$ functional image $(\mathrm{H} 4 \mathrm{a})$ & $0.269 * * *$ & 0.121 & $0.334 * * *$ & -1.814 \\
\hline & economic aspect $\rightarrow$ symbolic image $(\mathrm{H} 4 \mathrm{~b})$ & $0.364 * * *$ & $0.489 * * *$ & $0.301 * * *$ & 1.110 \\
\hline & economic aspect $\rightarrow$ experiential image $(\mathrm{H} 4 c)$ & $0.303 * * *$ & $0.401 * * *$ & $0.328 * * *$ & 0.369 \\
\hline & community aspect $\rightarrow$ functional image $($ H5a) & $0.112 * * *$ & $0.183 * *$ & $0.098^{*}$ & 1.050 \\
\hline & community aspect $\rightarrow$ symbolic image $(\mathrm{H} 5 \mathrm{~b})$ & $0.116^{* *}$ & 0.124 & $0.148 * *$ & -0.507 \\
\hline & community aspect $\rightarrow$ experiential image $(\mathrm{H5c})$ & $0.156^{* * *}$ & -0.035 & $0.256^{* * *}$ & $-4.097 * * *$ \\
\hline
\end{tabular}




\begin{tabular}{|c|c|c|c|c|c|c|c|c|c|}
\hline \multirow{3}{*}{$\begin{array}{l}\text { Brand } \\
\text { image }\end{array}$} & \multicolumn{2}{|c|}{ functional image $\rightarrow$ brand attitude(H6) } & \multicolumn{2}{|c|}{$0.677 * * *$} & \multicolumn{2}{|l|}{$0.666 * * *$} & $0.679 * * *$ & \multicolumn{2}{|c|}{-0.307} \\
\hline & \multicolumn{2}{|c|}{ symbolic image $\rightarrow$ brand attitude $(\mathrm{H} 7)$} & \multicolumn{2}{|c|}{$0.111 * * *$} & \multicolumn{2}{|l|}{-0.002} & $0.189 * * *$ & \multicolumn{2}{|c|}{$-2.508 *$} \\
\hline & \multicolumn{2}{|c|}{ experiential image $\rightarrow$ brand attitude $(\mathrm{H8})$} & \multicolumn{2}{|c|}{$0.199 * * *$} & \multicolumn{2}{|l|}{$0.296 * * *$} & $0.148 * *$ & \multicolumn{2}{|c|}{1.930} \\
\hline \multicolumn{3}{|c|}{ brand attitude $\rightarrow$ satisfaction(H9) } & \multicolumn{2}{|c|}{$0.964 * * *$} & \multicolumn{2}{|l|}{$0.949 * * *$} & $0.972 * * *$ & \multicolumn{2}{|c|}{-0.767} \\
\hline \multicolumn{3}{|c|}{ brand attitude $\rightarrow$ loyalty $(\mathrm{H} 10)$} & \multicolumn{2}{|c|}{$0.408 * *$} & \multicolumn{2}{|l|}{$0.483 * *$} & 0.325 & \multicolumn{2}{|c|}{0.573} \\
\hline \multicolumn{3}{|c|}{ brand attitude $\rightarrow$ future buying willingness $($ H11) } & \multicolumn{2}{|c|}{$0.208 * * *$} & \multicolumn{2}{|l|}{$0.318 * * *$} & $0.148 * *$ & \multicolumn{2}{|c|}{$2.172 *$} \\
\hline \multicolumn{3}{|c|}{ satisfaction $\rightarrow$ loyalty $(\mathrm{H} 12)$} & \multicolumn{2}{|c|}{$0.382 * *$} & \multicolumn{2}{|l|}{0.267} & $0.481^{*}$ & \multicolumn{2}{|c|}{-0.828} \\
\hline \multicolumn{3}{|c|}{ loyalty $\rightarrow$ future buying willingness(H13) } & \multicolumn{2}{|c|}{$0.767 * * *$} & \multicolumn{2}{|l|}{$0.683 * * *$} & $0.807 * * *$ & \multicolumn{2}{|c|}{-1.355} \\
\hline \multicolumn{10}{|c|}{ Competing model fit indices } \\
\hline$\chi^{2}$ & df & P-value & RMR & GFI & AGFI & NFI & RFI & CFI & RMSEA \\
\hline 3489.135 & 2068 & 1.687 & 0.086 & 0.819 & 0.777 & 0.886 & 0.865 & 0.950 & 0.033 \\
\hline
\end{tabular}

$* \mathrm{P}<0.05, * * \mathrm{P}<0.01, * * * \mathrm{P}<0.001$

\subsection{Comparison of Multi-Group Competing Model}

This research used the data in the age column to categorize the $\mathrm{X}$ and $\mathrm{Y}$ generations. According to Zemke, Raines \& Filipczak (2000), and Jennings (2000), those born between 1961 and 1979, about 35 53 years old now, are the X generation, and those born between 1980 and 2000, about 14 34 years old now, are the Y generation. This research took those 31 years of age or older as the $\mathrm{X}$ generation (216 copies) and those 30 years of age or younger as the $\mathrm{Y}$ generation (408 copies).

This research used the AMOS software to conduct a comparative analysis of the $\mathrm{X}$ and $\mathrm{Y}$ generations. The competing model is shown in Table 2, where GFI, AGFI and NFI are greater than 0.8 (Forza \& Filippini, 1998); CFI greater than 0.9 (Hair et al., 2006); RMSEA less than 0.05 (Brown \& Cudeck, 1933); $\chi 2 /$ df less than 3 (Chau $\& \mathrm{Hu}, 2001)$. Therefore, this model proved applicable.

From the analysis of the $\mathrm{X}$ and $\mathrm{Y}$ generation competing model, it was found that there were significant differences in four paths. The X-generation has a stronger and more positive impact than the Y-generation in two paths: including the impact of CSR of environment aspect on experiential brand image and the impact of brand attitude on future buying willingness. On the other hand, the Y-generation has a stronger and more positive impact than the X-generation in two paths: the impact of CSR of community aspect on experiential brand image, and the impact of symbolic brand image on brand attitude. The above significant differences between $\mathrm{X}$ and $\mathrm{Y}$ generations are the important findings of this research (see Table 2). Therefore, the hypothesis H14 is partially supported.

\section{Conclusions and Suggestions}

\subsection{Conclusions}

Much research has focused on CSR, but there has been little discussion dealing with the various aspects of CSR. This research began with the consumers' perception of five CSR aspects, and adopted an empirical study to explore the correlations among the dimensions, and to compare the differences between the two generations. The full model and competing model were thus established and some important findings were brought to light.

(1) Consumers' perception of the customer oriented CSR, the employee oriented CSR, the economically oriented CSR, and the community oriented CSR will impact on some brand image aspects but not all. Thus, the studies of the causes by a whole CSR and a whole brand image variable are insufficient. In the full model, three paths are not supported: the impact of customer oriented CSR on experiential brand image; the impact of environment oriented CSR on functional brand image and on experiential brand image. Thus, enterprises should pay more attention to strategies related to customer oriented CSR and environmentally oriented CSR, especially with respect to generation Y. However, in generation X there are 9 paths of no significance, including the impact of all of five aspects of CSR on three brand image aspects. Thus, generation X needs to be more deeply influenced by CSR strategies.

(2) Three aspects of business brand image all have significant and positive impacts on brand attitude. These are same as discussed by Kamins, Marks (1991) and Park et al. (1986), indicating that consumers' attitudes can be affected by functional image, symbolic image and experiential image. Thus, brand image is a key factor for enhancing consumers' attitudes towards a brand, especially with regard to generation Y.

(3) Consumers' brand attitudes have significant and positive impact on satisfaction, loyalty, and future buying willingness, especially with generation X. The results verify the arguments of Aaker (1991), Jamal and Goode (2001), Priester (2004), and Kotler (2000). This outcome shows that consumers' behaviors can be affected by 
their brand attitude, an attitude that leads to brand satisfaction, loyalty, and repurchasing.

(4) Consumers' satisfaction has significant and positive impact on loyalty, and loyalty has a positive impact on future buying willingness, especially in generation X. These outcomes are the same as those discussed by Reichheld and Sasser (1990), Anderson and Sullivan (1993), and Oliver (1999).

(5) The comparison between generation groups shows that the X-generation is more significant than the Y-generation in two paths. One is in the influence of environmentally oriented CSR on experiential brand image, and other is in the influence of brand attitude on future buying willingness. In the Y-generation, environment oriented CSR has significant and negative impact on the experiential brand image, indicating that enterprises need to work harder in their environmentally oriented CSR to make the Y-generation more aware of enterprises' efforts with environmental protection practices.

(6) T-test results show that the Y-generation is more significant than the X-generation in two other paths: the impact of community oriented CSR on experiential brand image, and the impact of symbolic brand image on brand attitude. When an enterprise provides various activities and events in a neighborhood, such as public welfare events, donations, art festivities, and so on, the Y-generation is supportive. Furthermore, when Y-generation consumers think an enterprise is more matching their self-style, their brand attitude will be strengthened.

(7) The impact of brand attitude on future buying willingness is significantly different between the two generations. The T-test shows that the X-generation has stronger impact than Y-generation. Therefore, brand attitude will have a greater impact on the X-generation regarding their future purchase.

\subsection{Management Implication}

This research has established a relationship model of CSR aspects, along with efficacious measuring variables, as important research concepts and tools that can be referenced by industries and researchers. Therefore, the outcome of this research should be practical and valuable.

The research found that a business undertaking its policy of CSR could lead consumers to purchase its products. For instance, if a business contributes and feeds back to the community, its bearing of the social responsibilities can lead consumers to identify themselves with the business image and become loyal to the brand, and ultimately the business will have an opportunity to fulfill its sustainability goal.

As mentioned, the business brand image, including functional image, symbolic image and experiential image, can bring about a positive brand attitude for consumers and this will then raise their satisfaction and foster a persistent loyal relationship. Certainly, future repurchasing will also be increased.

Therefore, this research suggests that enterprises strengthen their efforts to consolidate consumers' perceptions of CSR, so that consumers can ally themselves with a company and be more willing to buy its products. Also, a company must examine the main influential factors of CSR on different generations, in order to schedule appropriate actions and to plan efficacious marketing strategies. For example, with the X-generation, the environmental CSR is the most important aspect, since it can enhance their experiential brand image, and brand attitude and future buying willingness; in the case of the Y-generation, the community CSR is the most important aspect, since it can increase experiential brand image, symbolic brand awareness and further positively impact on consumers' brand attitudes.

\subsection{Study Limitations and Suggestions}

Different consumers attach various degree of importance to CSR and this may result in variation of brand image cognition, leading to a fluctuating strength of impact on brand attitude and buying behavior. Therefore, it is suggested that future studies adopt various variables to segment consumers into different categories, so that the proposed model can present individual features among different consumer groups and enhance the general value.

\section{References}

Aaker, D. A. (1996). Measuring brand equity across products and markets. California Management Review, 38(3), 102-120. http://dx.doi.org/10.2307/41165845

Aaker, J. (1991). The negative attraction effect? A study of the attraction effect under judgment and choice. Advances in Consumer Research, 18(1), 462-469,

Alexander, A., Francis, A., Kyire, L. A., \& Mohammed, H. (2014). The effect of corporate social responsibility on brand building. International Journal of Marketing Studies, 6(3), 126-113. http://dx.doi.org/10.5539/ijms.v6n3p126 
Alsmadi, S., \& Alnawas, I. (2012). Consumer rights today: Are they in business or out of business? International Journal of Marketing Studies, 4(1), 159-167. http://dx.doi.org/10.5539/ijms.v4n1p159

Anderson, E. W., \& Sullivan, M. W. (1993). The antecedents and consequences of customer satisfaction for firms. Marketing Science, 12, 125-143. http://dx.doi.org/10.1287/mksc.12.2.125

Arjun, C. (1999). Dose brand loyalty mediate brand equity outcomes? Journal of Marketing Theory and Practice, 7(2), 136-146.

Becker-Olsen, K. L., \& Hill, R. (2006). The impact of sponsor fit on brand equity. Journal of Service Research, 9(1), 73-83. http://dx.doi.org/10.1177/1094670506289532

Bennett, R., \& Sharyn, R. T. (2002). A comparison of attitudinal loyalty measurement approaches. Journal of Brand Management, 9(January), 193-209. http://dx.doi.org/10.1057/palgrave.bm.2540069

Blattberg, R. C., \& Neslin, S. A. (1990). Sales Promotion Concepts, Methods, and Strategies. New York: Prentice-Hall.

Boonpattarakan, A. (2012). An experimental design to test the main and interaction effects of CSR involvement, brand naming and pricing on purchase intentions in Thailand. International Journal of Business and Management, 7(16), 62-79. http://dx.doi.org/10.5539/ijbm.v7n16p62

Brandt, M. (1998). Don't dis your brand. MC Technology Marketing Intelligence, 18(1), 46-47.

Brown, M. W., \& Cudeck, R. (1993). Alternatives ways of assessing model fit. In K. A. Bollen \& J. S. Long (Eds.), Testing Structural Equation Model (pp. 136-162). Newbury Park, CA: Sage.

Brown, T. J., \& Dacin, P. A. (1997). The company and the product: Corporate associations and consumer product responses. Journal of Marketing, 61(1), 68-84. http://dx.doi.org/10.2307/1252190

Brunk, K. H. (2010). Exploring origins of ethical company/brand perceptions - A consumer perspective of corporate ethics. Journal of Business Research, 63(3), 255-262. http://dx.doi.org/10.1016/j.jbusres.2009.03.011

Burton, S., Lichtenstein, D. R., Netemeyer, R. G., \& Garretson, J. A. (1998). A scale for measuring attitude toward private label products and an examination of its psychological and behavioral correlates. Journal of the Academy of Marketing Science, 26(4), 293-306. http://dx.doi.org/10.1177/0092070398264003

Carmines, E. G., \& Maclver, J. P. (1981). Analyzing models with unobserved variables. In G. W. Bohrnstedt \& E. F. Borgatta (Eds.), Social Measurement: Current Issues (pp. 65-115). CA: Sage Publications.

Chau, P. Y. K., \& Hu, P. J. H. (2001). Information technology acceptance by individual professional: A model $\begin{array}{lllll}\text { comparison } & \text { approach. } & \text { Decision } & \text { Sciences, } & 32(4),\end{array}$ http://dx.doi.org/10.1111/j.1540-5915.2001.tb00978.x

Childers, T. L., \& Rao, A. R. (1992). The influence of familial and peer-based reference groups on consumer decisions. Journal of Consumer Research, 19, 198-211. http://dx.doi.org/10.1086/209296

Clarkson, M. B. E. (1995). A stakeholder framework for analyzing and evaluating corporate social performance. Academy of Management Review, 20(1), 92-117.

Cotte, J., \& Stacy, L. W. (2004). Families and innovative consumer behavior: A triadic analysis of sibling and parental influence. Journal of Consumer Research, 31(June), 78-86. http://dx.doi.org/10.1086/383425

Cretu, A. E., \& Brodie, R. J. (2007). The influence of brand image and company reputation where manufacturers market to small firms: A customer value perspective. Industrial Marketing Management, 36(2), 230-240. http://dx.doi.org/10.1016/j.indmarman.2005.08.013

Dodds, W. B., Monroe, K. B., \& Grewal, D. (1991). Effects of price, brand, and store information on buyers' product evaluations. Journal of Marketing Research, 28(3), 307-319. http://dx.doi.org/10.2307/3172866

Esrock, S. L., \& Leichty, G. B. (1998). Social responsibility and corporate Web pages: Self-presentation or agenda-setting. Public Relations Review, 24(3), 305. http://dx.doi.org/10.1016/S0363-8111(99)80142-8

Farr, A., \& Hollis, N. (1997). What do you want your brand to be when it grows up? Big and strong? Journal of Advertising Research, 37(6), 23-36.

Fombrun, C., \& Shanley, M. (1990). What's in a name? Reputation building and corporate strategy. Academy of Management Journal, 33(2), 233-258. http://dx.doi.org/10.2307/256324

Forza, C., \& Filippini, R. (1998). TQM impact on quality conformance and customer satisfaction: A causal 
model. International Journal of Production Economics, 55, 1-20. http://dx.doi.org/10.1016/S0925-5273(98)00007-3

Fournier, S. (1998). Consumers and their brands: Developing relationship theory in consumer research. Journal of Consumer Research, 24(4), 343-353. http://dx.doi.org/10.1086/209515

Freeman, R. E. (1984). Strategic Management: A Stakeholder Approach. Boston: Pitman.

Giannarakis, G., \& Theotokas, I. (2011). The effect of financial crisis in corporate social responsibility performance. International Journal of Marketing Studies, 3(1), 2-10. http://dx.doi.org/10.5539/ijms.v3n1p2

Goi, C. L., \& Yong, K. H. (2009). Contribution of public relations (PR) to corporate social responsibility (CSR): A review on Malaysia perspective. International Journal of Marketing Studies, 1(2), 46-49. http://dx.doi.org/10.5539/ijms.v1n2p46

Goodman, J. (1989). The Nature of Customer Satisfaction. Quality Progress, 37-40.

Gounaris, S., \& Stathakopoulos, V. (2004). Antecedents and consequences of brand loyalty: An empirical study. Journal of Brand Management, 11(4), 283-306. http://dx.doi.org/10.1057/palgrave.bm.2540174

Grewal, D., Krishnan, R. R., Baker, J., \& Borin, N. (1998). The effects of store name, brand name and price discounts on consumers' evaluations and Purchase intentions. Journal of Retailing, 74(3), 331-352. http://dx.doi.org/10.1016/S0022-4359(99)80099-2

Hair, J. F. Jr., Black, W. C., Babin, B. J., Anderson, R. E., \& Tatham, R. L. (2006). Multivariate Data Analysis (6th ed.). New Jersey: Prentice Hall.

He, H., \& Li, Y. (2011). CSR and service brand: The mediating effect of brand identification and moderating effect of service quality. Journal of Business Ethics, 100(4), 673-688. http://dx.doi.org/10.1007/s10551-010-0703-y

Heckler, S. E., Childers, T. L., \& Arunachalam, R. (1989). Intergenerational influences in adult buying behaviors: An examination of moderating factors. In Thomas K. Srull (Ed.), Advances in Consumer Research (pp. 276-284). Provo, UT: Association for Consumer Research.

Howard, J. A. (1994). Buyer Behavior in Marketing Strategy (2nd ed.). Prentice-Hall, Inc.

Jamal, A., \& Goode, M. (2001). Consumers' product evaluation: A study of the primary evaluative criteria in the precious jewelers market in the UK. Journal of Consumer Behaviour, 1(2), 140-155. http://dx.doi.org/10.1002/cb.61

Jennings, A. T. (2000). Hiring generation X. Journal of Accountancy, 189, 55-59.

Joreskog, K. G., \& Sorbom, D. (1989). LISREL 7 Use's Reference Guide. Chicago: Scientific Software.

Kaiser, H. F. (1958). The varimax criterion for analysis rotation in factor analysis. Psychometrics, 23(3), 187-200. http://dx.doi.org/10.1007/BF02289233

Kamins, M. A., \& Marks, L. J. (1991). The perception of kosher as a third party certification claim in advertising for familiar and unfamiliar brands. Journal of the Academy of Marketing Science, 19(3), 177-185. http://dx.doi.org/10.1007/BF02726494

Kerlinger, F. N. (1978). Foundation of Behavioral Research. NY: McGraw-Hill.

Kotler, P. (2000). Future Markets. Executive Excellence, 17(2), 6.

Kotler, P., \& Lee, N. (2005). Best of Breed: When it comes to gaining a market edge while supporting a social cause, corporate social marketing, leads the pack. Social Marketing Quarterly, 11(3/4), 91-103. http://dx.doi.org/10.1080/15245000500414480

Kotler, P., G., Armstrong, J. S., \& Wing, V. (1999). Principals of Marketing (2nd European ed.). New York: Prentice Hall.

Laroche, M., Kim, C., \& Zhou, L. (1996). Brand familiarity and confidence as determinants of purchase intention: An empirical test in a multiple brand context. Journal of Business Research, 37(2), 115-120. http://dx.doi.org/10.1016/0148-2963(96)00056-2

Lichtenstein, D. R., Drumwright, M. E., \& Braig, B. M. (2004). The effect of corporate social responsibility on customer donations to corporate-supported nonprofits. Journal of Marketing, 68(4), 16-32. http://dx.doi.org/10.1509/jmkg.68.4.16.42726

Maignan I., \& Ferrell, O. C. (2001). Corporate citizen as a marketing instrument - concepts, evidence and 
$\begin{array}{lllll}\text { research directions. European Journal of } & \text { Marketing, } 35(3 / 4),\end{array}$ http://dx.doi.org/10.1108/03090560110382110

Mandrik, C. A., Edward, F. F., \& Yeqing, B. (2005). Intergenerational Influence: Roles of conformity to peers and communication effectiveness. Psychology \& Marketing, 22(10), 813-832. http://dx.doi.org/10.1002/mar.20087

Mejri, M., \& De Wolf, D. (2012). Analysis of retailers' communication approaches in sustainability and social responsibility reports. International Journal of Marketing Studies, 4(2), 30-44.

Moore, E. S., William, L., \& Richard, J. L. (2002). Passing the torch: intergenerational influences as a source of brand equity. Journal of Marketing, 66, 17-37. http://dx.doi.org/10.1509/jmkg.66.2.17.18480

Neal, W. D. (2000). Three's not the magic number: when measuring loyalty satisfactorily, don't measure CS. Marketing News, 19.

Nunnally, J. C. (1978). Psychometric Theory. NY: Mcgraw-Hill.

Oliver, R. L. (1980). A cognitive model of the antecedents and consequences of satisfaction decisions. Journal of Marketing Research, 17(4), 460-469. http://dx.doi.org/10.2307/3150499

Oliver, R. L. (1999). Whence consumer loyalty? Journal of Marketing, 63(4), 33-44. http://dx.doi.org/10.2307/1252099

Park, C., Jaworski, B. J., \& Maclnnis, D. J. (1986). Strategic brand concept-image management. Journal of Marketing, 50(4), 135-145. http://dx.doi.org/10.2307/1251291

Pivato, S., Misani, N., \& Tencati, A. (2008). The impact of corporate social responsibility on consumer trust: the case of organic food. Business Ethics: A European Review, 17(1), 3-12. http://dx.doi.org/10.1111/j.1467-8608.2008.00515.x

Porter, M. E., \& Kramer, M. R. (2006). Strategy \& society: The link between competitive advantage and corporate social responsibility. Harvard Business Review, 84(12), 78-92.

Priester, J. R., Godek, J., Nayakankuppum, D. J., \& Park, K. (2004). Brand congruity and comparative advertising: When and why comparative advertisements lead to greater elaboration. Journal of Consumer $\begin{array}{lllll}\text { Psychology (Lawrence } & \text { Erlbaum 14(1/2), }\end{array}$ http://dx.doi.org/10.1207/s15327663jcp1401\&2_13

Reichheld, F. F., \& Cook, S. (1996). Quest for loyalty: Creating value through partnership (Hardcover). Harvard Business School Press Books, 1, 278.

Reichheld, F. F., \& Sasser Jr., W. (1990). Zero defections: Quality comes to services. Harvard Business Review, 68(5), 105-111.

Reynolds, T. J., \& Gutman, J. (1984). Advertising Is Image Management. Journal of Advertising Research, 24(1), 27-37.

Romaniuk, J., \& Sharp, B. (2003). Measuring brand perceptions: Testing quantity and quality. Journal of $\begin{array}{lllll}\text { Targeting, } \quad \text { Measurement } \& \text { Analysis for Marketing, } & \text { 11(3), } 218 .\end{array}$ http://dx.doi.org/10.1057/palgrave.jt.5740079

Schiffman, L. G., \& Kanuk, L. L. (2000). Consumer Behavior. Upper Saddle River, NJ: Prentice Hall.

Segars, A. H., \& Grover, V. (1993). Re-examining perceived ease of use and usefulness: A confirmatory factor analysis. MIS Quarterly, 17(4), 517-525. http://dx.doi.org/10.2307/249590

Sen, S., Bhattacharya, C. B., \& Korschun, D. (2006). The role of corporate social responsibility in strengthening multiple stakeholder relationships: A field experiment. Journal of the Academy of Marketing Science, 34(2), 158-166. http://dx.doi.org/10.1177/0092070305284978

Shah, R. H., \& Mittal, B. (1997). Toward a theory of intergenerational influence in consumer behavior: An exploratory essay. In M. Brucks \& D. J. MacInnis (Eds.), Advances in Consumer Research (Vol. 24, pp. 55-60). Provo, UT: Association for Consumer Research.

Shamma, H. M., \& Hassan, S. S. (2011). Integrating product and corporate brand equity into total brand equity measurement. International Journal of Marketing Studies, 3(1), 11-20. http://dx.doi.org/10.5539/ijms.v3n1p11

Waddock, S. A., Bodwell, C., \& Graves, S. B. (2002). Responsibility: The new business imperative. Academy of 
Management Executive, 16(2), 132-148. http://dx.doi.org/10.5465/AME.2002.7173581

Zeithaml, V. A. (1988). Consumer perceptions of price, quality and value: a means-end model and synthesis of evidence. Journal of Marketing, 52(3), 2-22. http://dx.doi.org/10.2307/1251446

Zemke, R., Raines, C., \& Filipczak, B. (2000). Generations at work: Managing the clash of veterans, boomers, xers, and nexters in your workplace. American Management Association, New York.

\section{Copyrights}

Copyright for this article is retained by the author(s), with first publication rights granted to the journal.

This is an open-access article distributed under the terms and conditions of the Creative Commons Attribution license (http://creativecommons.org/licenses/by/3.0/). 